\title{
The internationalization of Chinese companies: firm characteristics, industry effects and corporate governance
}

\author{
Gerhard Kling $^{\mathrm{a}}$ and Utz Weitzel ${ }^{\mathrm{b}}$ \\ ${ }^{\mathrm{a}}$ University of Southampton, ${ }^{\mathrm{b}}$ Radboud University Nijmegen \\ THIS IS NOT THE FINAL (POST-REVIEW) VERSION \\ YOU FIND THE FINAL VERSION HERE:
}

Kling, G. and U. Weitzel (2012) The internationalization of Chinese companies: firm characteristics, industry effects and corporate governance, Research in International Business and Finance, forthcoming

A prominent issue in the internationalization of Chinese firms is that many are stateowned enterprises (SOEs) and that corporate governance in China is highly idiosyncratic. This paper identifies firm characteristics, industry effects and corporate governance mechanisms that foster internationalization. We find that Chinese crossborder mergers create shareholder value, but not more than domestic expansions. Corporate governance mechanisms matter, jointly and individually. While stateownership predicts fewer cross-border mergers, a favourable board structure and corporate transparency explains higher M\&A returns. As in more mature markets, firm- and industry-specific determinants also affect M\&As in China. 


\section{Introduction}

In 2005, Graham and Pettis asked the question: "who's afraid of CNNOC (China National Offshore Oil Corporation)?" and started a media frenzy. The general perception has been that Chinese firms acquire foreign companies and assets at an alarming rate. The main issue of the internationalization of Chinese firms is that most are state-owned enterprises (SOEs); hence, internal and external corporate governance mechanisms are very different. In contrast to research in political economy and corporate governance, the literature in international business and finance often approaches the internationalization of Chinese firms more generically without accounting for the peculiarities of the Chinese governance system (Child and Rodrigues, 2005). An exception is the study by Cui and Jiang (2009) that contends that SOEs face barriers to enter foreign markets due to local political opposition.

Our study goes beyond the distinction of SOEs and private entities and incorporates a broad range of corporate governance measures. It focuses on mergers and acquisitions (M\&A) of Chinese companies and hence a particular mode of entry. Apart from studying cross-border M\&A, it also includes domestic transactions to analyse differences in underlying drivers and success. Only a few studies focus on outward FDI and they use aggregated data (Liu et al., 2005). In contrast, our study compiles firm-level data on cross-border M\&A. In particular, the study tests the impact of three theoretical perspectives on the internationalization through M\&A and its success. The first perspective underlines the importance of external and internal governance mechanisms and is based on the corporate governance and political economy literature. Second, by drawing on the Resource-based View, we incorporate firm specific proxies that contribute to better access to resources and capabilities, including the firm's past acquisition experience and financing capabilities. Third, industry specific effects can influence the degree and success of internationalization. 
Our contribution is threefold. First, this paper extends the FDI literature by analyzing the determinants of cross-border M\&A initiated by Chinese acquirers. Joint hypothesis tests confirm that not only governance mechanisms, but also firm- and industry-specific factors affect the decision to acquire foreign assets. Second, this paper adds to the international diversification literature by analyzing the determinants and performance of Chinese crossborder acquirers. In particular, it supports recent evidence on the internationalization of emerging market multinationals (Aybar and Ficici, 2009) by showing that Chinese crossborder M\&As do not create more shareholder value than domestic transactions. For domestic M\&A, these results also add to the limited but growing literature on Chinese M\&A performance. Third, with regard to the corporate governance literature, in particular for emerging markets multinationals, the paper identifies governance mechanisms with explanatory power: the decision to acquire foreign assets is negatively affected by state ownership and positively by the separation of the positions of CEO and chairman of the board. The latter governance mechanism also influences the success of M\&A. In addition, corporate transparency measured by disclosure of executives' compensation and issuing shares on the Hong Kong Stock Exchange (H-shares) enhances M\&A performance.

The paper is structured as follows. The second section develops the conceptual framework, followed by the development of hypotheses in Section 3. The fourth section discusses the dataset and construction of variables. Section 5 reports and discusses the empirical results, and Section 6 concludes.

\section{The conceptual framework}

Cui and Jiang (2009) conduct a survey of 138 Chinese firms and determine whether firms choose joint ventures or wholly owned subsidiaries to enter foreign markets. While they survey firms that internationalized, we focus on the first step, whether firms internationalize 
and how successful they are in doing this. Our study refers to M\&A and thus ignores greenfield investments, which is due to two reasons. First, before the start of our sample period (in 1999), 83\% of all FDI was conducted through M\&A (UNCTAD, 2000, p.14). Hence, the decision to internationalize overlaps with the decision to acquire foreign targets. Second, there is no reliable data source that identifies greenfield investments. As pointed out by Cui and Jiang (2009), even aggregated data on FDI in China is not reliable. ${ }^{1}$ One solution, used by Cui and Jiang (2009), is to conduct a survey. However, next to a limited number of observations and a possible self-reporting bias, most surveys do not allow for time-varying patterns - except if the firms are approached several times (dynamic surveys).

Most studies on Chinese M\&A focus on domestic transactions. Overall, the results are ambiguous. For the year 1997, Sun and Wang (1999) find that the performance of reorganized companies significantly improved, but they do not find more general support for this relationship. For the same year, Chen and Zhang (1999) argue that the cumulative abnormal returns of reorganized firms increased, albeit not statistically significant. For the period from 1994 to 1998, Feng and $\mathrm{Wu}$ (2001) contend that reorganized companies exhibited operative performance improvements, although the performance declined since 1998. For a similar period from 1993 to 2002, Zhang (2003) show that stock returns of acquiring firms decreased. From 1999 to 2000, however, $\mathrm{Li}$ and Chen (2002) report positive abnormal returns for acquiring firms. One reason for these ambiguous results could be that many studies do not account for different forms of equity transfers. ${ }^{2}$

\footnotetext{
${ }^{1}$ The Report of Industrial Enterprise Statistics published by the National Bureau of Statistics of China is the best data source for Chinese companies, as it covers all firms with revenues exceeding 5 million Renminbi. However, the report does not include information on outward FDI. The Ministry of Commerce provides some data on FDI - but the data quality and coverage is not comprehensive.

${ }^{2}$ Gao \& Kling (2008) distinguished between transactions among SOEs, nationalisations, privatisations and transactions between independent companies. Yet their event study is only based on 134 transactions.
} 
We suggest that Chinese mergers are more context-specific, involving a rich spectrum of firm-, deal- and industry determinants, as well as internal and external governance mechanisms. This particularly applies to cross-border M\&A decisions, which most of the prior studies neglect. ${ }^{3}$

\section{Development of hypotheses}

Recent research on the success of diversification through internationalization paints a rather bleak picture for shareholders. Gao et al. (2008) find that internationally and geographically dispersed US firms experience a significant valuation discount. This effect is especially pronounced for diversifications via M\&A. This stands in contrast to Gande et al. (2009), who contend that valuation levels of US firms increases with global diversification. As a possible explanation for the contrasting results, Doukas and Kan (2006) argue that the global diversification discount may only apply to shareholders, whereas bondholders benefit from risk-reduction. Particularly for multinationals from emerging markets, Aybar and Ficici (2009) show that cross-border M\&As do not create value and that more than half of the transactions even point to value destruction. Thus, for shareholders of Chinese cross-border acquirers we expect the following:

Hypothesis 1. In comparison with domestic M\&As, shareholders of Chinese acquirers do not benefit from cross-border M\&As.

Firm specific drivers of internationalization can be based on the Resource-based View, which propounds that firms can attain competitive advantage if they possess resources not held by others (Wernerfelt, 1984). Amit and Schoemaker (1993) regard resources as the first step in the value chain and the driver of capabilities, competencies and competitive advantage.

\footnotetext{
${ }^{3}$ An exception is Cui and Jiang (2009), who select a strategic behaviour approach to model the mode of entry of Chinese firms. Our focus, however, is on drivers of M\&A internationalisation and cross-border merger success.
} 
In contrast to resources, capabilities are firm-specific (Barney et al., 2001). In addition, firms with competitive advantage possess the ability to extract more value from M\&A, for synergies can be realised easier, and better access to resources (i.e. finance) provides additional synergies. Accordingly, firm-specific variables that improve access to resources and capabilities translate into competitive advantage, which in turn stimulates internationalization.

Hypothesis 2. Chinese firms with good access to resources and capabilities possess competitive advantage that enhances the likelihood of internationalization through crossborder $M \& A$.

Hypothesis 3. Shareholders of Chinese acquirers with better access to resources and capabilities benefit more from $M \& A$, as the value creation potential is higher due to the acquirer's superior ownership.

In the merger literature there is ample evidence that corporate and public governance mechanisms affect cross-border merger activity and success (Rossi and Volpin, 2004; Weitzel and Berns, 2006). For Chinese FDI, Luo et al. (2010) use a political economy view to assess the impact of policy changes on outward FDI. It is also important to account for regional disparities in terms of external governance, for the quality of institutions differs substantially within China (Fan \& Wang, 2004). In China, corporate governance is a key issue for shareholders, as fraud and tunnelling are widespread (Gao and Kling, 2008a). Zhang (2007) argue that relying on the market mechanism is not sufficient to enhance corporate governance in China. Instead, legal sanctions and enforcement need to be strengthened. State ownership and control is a key issue in Chinese corporate governance. Even after years of privatization, SOEs still play a major role in China. Apart from state influence through share ownership, the State-owned Asset Supervision and Administration Commission (SASAC) exercises 
considerable administrative control. ${ }^{4}$ For instance, SASAC can appoint top executives and plays a vital role in M\&As between SOEs. Quiang (2003) contend that the state directly or indirectly appoints $69 \%$ of all directors and CEOs based on figures for 2001. Accordingly, we state the following hypotheses.

Hypothesis 4. Chinese acquirers with better internal and external corporate governance conduct more cross-border M\&A, because they have easier access to foreign markets, and investors have more trust in their quality of governance.

Hypothesis 5. Chinese acquirers with better internal and external corporate governance exhibit better value creation potential from $M \& A$, because their superior governance helps to realise synergies.

Apart from firm specific resources and capabilities, the industry structure has a profound impact on internationalization (Yip, 1992). In addition, corporate governance in China is partially industry-specific (i.e. protected industries). Accordingly, we derive the following hypotheses.

Hypothesis 6. Industry-specific effects determine the propensity to conduct cross-border $M \& A$.

Hypothesis 7. The success of cross-border and domestic M\&A depends on industry-specific effects.

\section{Data and definition of variables}

The M\&A data refers to the Thomson Reuters Financial M\&A database (SDC database). We refine the dataset to include only: (1) acquisitions announced between January 1, 2001 and December 31, 2008; (2) Chinese acquirers that are publicly listed on one (or more) Chinese stock exchanges in Hong Kong, Shanghai and Shenzhen; (3) acquisitions that do not involve a

\footnotetext{
${ }^{4}$ SASAC founded in May 2003 supervises the 196 largest SOEs.
} 
recapitalization, repurchase of own shares, or a spin-off to existing shareholders; (4) where the transaction value of the deal is recorded in the database. This creates a dataset of 4374 domestic and cross-border transactions by Chinese acquirers. We include corporate governance measures from the China Stock Market Research Series (CSMAR) and financial variables from the CSMAR and the SDC database. This subset contains 2237 observations.

In order to test Hypotheses 1-7, we employ two dependent variables. For Hypotheses $1,2,4$, and 6 , we distinguish between domestic and cross-border M\&As by constructing a dummy variable (cross) that indicates the acquisition of a non-Chinese target. To test Hypotheses 1, 3, 5, and 7, we need a measure of M\&A success. Some studies on M\&As in China, particularly in conjunction with the restructuring of SOEs, use operational measures of performance derived from balance sheets (Sun and Wang, 1999). As there are many irregularities in the accounting of reorganized firms, balance sheet figures do not reflect firm performance reliably (Chen \& Yuan, 1998). An alternative approach is the stock return event study, which has been and still is the predominant method (MacKinlay, 1997; Zollo and Meier, 2008). Significant changes in share prices at the announcement of M\&As are likely to reflect changes of future firm value. Following Fuller et al. (2002) and Dong et al. (2006), we estimate a modified market adjusted model and compute cumulated abnormal returns (CARs) for the three day period around the announcement date $(-1,+1)$.

CAR_1 $\mathbb{1}_{i}=\sum_{t=1}^{T=3}\left(r_{i}-r_{m}\right)$

Here, CAR_ $l_{i}$ is acquirer $i$ 's cumulated abnormal return, winsorized between $5 \%$ and $95 \%, r_{i}$ is the stock return on acquirer $i$ and $r_{m}$ is the market return of all other Chinese firms at the same stock exchange. We compute short term CARs over three days, because the fallibility of asset pricing models for the expected return $r_{m}$ increases with the event window 
(Sudarsanam, 2003). ${ }^{5}$ As there is no uniquely infallible model, short term event windows are less dependent on model specifications, compared to long-term windows.

The appendix contains the definition of all variables, consisting of (1) deal-related variables, (2) firm-specific variables, (3) internal and external governance measures, and (4) industry-specific effects. Deal-related variables: In line with the literature on M\&A (Martynova and Renneboog, 2008; Sudarsanam, 2003), we control for a number of transaction-specific variables. The method of payment can influence the success of M\&A, for cash mergers are regarded as positive signals (Tichy, 2001). Therefore, we indicate whether a transaction has been primarily a cash merger defined as $90 \%$ cash offer compared to the total offer price (cash). M\&A transactions are classified based on whether the acquirer takes control (merger), acquirers an additional equity stake after taking control (acq) or buys a minority stake ( $\mathrm{min}$ ). Moreover, we distinguish between horizontal (hor) and vertical mergers based on two-digit SIC codes of acquirers and targets. The relative size of the deal (rel_size) is a key indicator of M\&A success and of the propensity to conduct M\&A (Moeller et al., 2004). Finally, we account for tender offers (tend) and the reasons for selling a target firm to an acquirer, namely divestitures (divest) and privatisations (privat).

Firm-specific variables: We account for the size of the acquirer (size) as a proxy for access to resources and the capability to allocate resources (Agarwal and Ramaswami, 1992), financial leverage as a proxy for access to finance (leverage), and profitability measured by the return on equity $(R O E)$. High profitability indicates that acquirers possess significant competitive advantage. Apart from capabilities directly linked to the business model, one could argue that capabilities can be related to the acquisition process. Acquirers with a track record of past acquisitions measured by the number of transactions (active) and previously

\footnotetext{
${ }^{5}$ For robustness we also ran the analyses reported in this paper with CARs for different event windows, namely CAR $(-1 ; 0)$ and $\operatorname{CAR}(0 ;+1)$. The results are qualitatively similar with varying significances.
} 
purchased goodwill relative to total assets ( $\operatorname{good}$ ) might develop M\&A specific capabilities that could make future M\&A more likely and successful. To control for a potential misvaluation effect, the study incorporates the acquirer's valuation level measured by Tobin's Q (tobin_q). Dong et al. (2006) show that there is a negative relation between acquirer's overvaluation and stock market reactions after acquisitions.

Governance variables: A substantial proportion of all M\&A activities are government driven due to the restructuring of SOEs, privatisations and nationalisations. Hence, we indicate whether acquirers are SOEs (gov). Following Liu and Sun (2005), we apply the pyramid shareholding concept to identify the ultimate ownership of the state. Further, share ownership by the acquirer's management (own_share) may give rise to conflicts of interest in a merger (Hartzell et al., 2004). To measure ownership concentration, we compute the Herfindahl index, defined as the squared sum of share ownership of the ten largest shareholders. To obtain a standardized measure of concentration, we subtract the lowest measured index in the sample from each observation's index and divided the outcome by the difference of the highest and lowest index in the sample. The standardized Herfindahl index $(H I)$ provides values in the range of zero (no concentration) and one (highest concentration). Bai et al. (2004) argue that firms that issued both A-shares and B-shares (or H-share) exhibit better corporate transparency and higher market valuation, as they have to adopt dual reporting procedures. Hence, we include two dummy variables for firms that issue B- or Hshares (b_share, $\left.h \_s h a r e\right)$. An effective board should enhance firm's transparency and monitoring. In general, the board's efficiency depends on its size and independence. Jensen (1993) and Yermack (1996) argue that a small board (board) is more effective. The independence of the board depends on the ratio of independent board members (independent) and whether the CEO is also the chairman of the board (duality). Further, the disclosure of top executives' salaries (disclosure) also reveals a board's attitude towards transparency. To 
account for regional disparities in the external governance environment, we use Fan and Wang's (2004) regional market function index. The index quantifies the degree of development of the regional legal system, enforcement and intermediary organizations (i.e. accounting firms and the media) (legal).

\section{Results and discussion}

\subsection{Descriptive analysis}

Chinese firms exhibit some interesting peculiarities not only concerning corporate governance but also their M\&A activities. In contrast to other developed or emerging markets, we do not observe more than one bidder for a target firm. In addition, only eight transactions were regarded as hostile and only one merger could be classified as distressed merger. Table 1 presents descriptive statistics for our sample highlighting the number and type of transactions, method of payment, state involvement, deal volumes, and measures of success.

\section{(Insert Table 1)}

From 2001 to 2004 , the number of transactions increased rapidly by $413 \%$ - but after 2004 there was a considerable slowdown of M\&A activity that resulted in a moderate increase of $21 \%$ until 2008. In China, M\&A transactions have been influenced by the restructuring of SOEs. The slowdown in privatisations coincided with the trough in M\&A activity since 2004 . The involvement of the state reached its peak at $51 \%$ in 2003 and declined afterwards to $29 \%$. However, deal volume has increased steadily, although the volume per transaction expanded mainly since 2005 after the privatisation wave. Another unusual fact is the predominant role of cash mergers, which accounted for $96.9 \%$ of all M\&A. Hence stock is not yet an important acquisition currency in China. Compared to developed markets, Chinese acquirers conducted fewer cross-border transactions, as only $4.8 \%$ of all transactions involved a foreign target, 
compared to $20.3 \%$ in the US and $38.79 \%$ in the UK. ${ }^{6}$ In fact, the tendency to internationalize through cross-border M\&A reached its peak of around $13.3 \%$ at the beginning of the investigation period and fell thereafter. These descriptive findings do not support the media frenzy concerning the wave of acquisitions conducted by Chinese firms. The relatively high proportion of domestic M\&A can be partly explained by the restructuring of SOEs. When excluding the government-led restructuring, cross-border M\&A accounts for $6.1 \%$ of all transactions, which still is significantly below developed markets. M\&A seems to be rather successful for acquirers indicated by positive means of cumulated abnormal returns (CAR_l). Value weighted CARs are lower than equally weighted measures; thus, larger deals are less successful, which is in line with evidence from developed markets (Moeller et al., 2005).

Table 2 reports corporate governance indicators of acquiring firms from 2001 to 2008. Most notably, concentration of ownership measured by the Herfindahl index $(H I)$ declined over time, which also illustrates the reduction of state ownership. Managers' shareholding (own_share) has been traditionally low in China and does not seem to exhibit any long-term trend. The ratio of independent members of the board of directors (independent) showed a steady increase from $2 \%$ to $33 \%$, which has been driven by government legislation requesting that at least a third of board members need to be independent. ${ }^{7}$ The size of the board (board) increased until 2004 but declined thereafter, which would support the view that internal governance improved, for large boards are commonly believed to be less effective (Jensen, 1993; Yermack, 1996). Another indication about the improvement of the board's effectiveness is the increase in the duality measure. Duality indicates whether the two positions, CEO and chairman of the board, are held by different people. The disclosure of the

\footnotetext{
${ }^{6}$ The values for the US and UK originate from the same database and are generated with queries that are analogous to the Chinese sample in this study.

${ }^{7}$ This surge might have improved internal governance - but it might be also just a 'box-ticking' exercise for companies to prove that they comply with new government legislation.
} 
salaries of top executives (disclose) became more common over time; in fact most acquirers disclose this information since 2007. This pattern reflects a change in policy. At the beginning of our investigation period, disclosure of executives' salaries was voluntary. Due to the lack of voluntary disclosure, the government decided to change its guidelines and made it a mandatory requirement (at least to disclose the sum of salaries but not the individual salaries). In spite of becoming a mandatory item, some companies do not disclosure managers' compensation. Issuing B or $\mathrm{H}$-shares (B-share, $H$-share) has become less relevant over time. Due to tighter regulations, companies that issue $\mathrm{B}$ and $\mathrm{H}$-share have to follow more rigorous guidelines in terms of disclosure. On the aggregated level, the external regional governance environment remained almost unchanged (legal).

\section{(Insert Table 2)}

Table 3 reports the pairwise correlations for all variables, as well as their variance inflation factors (VIF). All VIF values are well below the established cut-offs of 5.3 (Hair et al., 1992) and 10 (Studenmund, 1992). Thus, multicollinearity is not an issue.

\section{(Insert Table 3)}

\subsection{Cross-border versus domestic $M \& A$ activity}

Based on our hypotheses, we employ the firm-specific variables related to the Resource-based View and the governance variables to analyse the propensity to conduct cross-border M\&A (Hypotheses 2 and 4). In addition, we account for industry-specific effects in line with Hypothesis 6. Because of the binary nature of the dependent variable, namely to internationalize through $\mathrm{M} \& \mathrm{~A}$ or not (cross), we apply a probit model, which takes the following form. 


$$
\begin{aligned}
\operatorname{cross}_{\mathrm{it}}=\alpha+ & \sum_{j=1}^{7} \beta_{j} D_{j}+\sum_{k=1}^{62} \gamma_{k} D_{k}+\delta_{1} \text { leverage }_{\mathrm{it}}+\delta_{2} \text { size }_{\mathrm{it}}+\delta_{3} \text { ROE }_{\mathrm{it}}+\delta_{4} \text { good }_{\mathrm{it}} \\
& +\delta_{5} \text { active }_{\mathrm{it}}+\theta \text { tobin }_{\mathrm{q}_{\mathrm{it}}}+\vartheta_{1} \text { gov }_{\mathrm{it}}+\vartheta_{2} \text { own }_{\text {share }}+\vartheta_{3} H_{\mathrm{it}} \\
& +\vartheta_{4} \text { independent }_{\mathrm{it}}+\vartheta_{5} \text { board }_{\mathrm{it}}+\vartheta_{6} \text { duality }_{\mathrm{it}}+\vartheta_{7} \text { disclosure }_{\mathrm{it}} \\
& +\vartheta_{8} B_{\text {share }} \text { shat }_{\mathrm{it}}+\vartheta_{9} H_{-} \text {share }_{\mathrm{it}}+\vartheta_{10} \text { legal }_{\mathrm{it}}+\varepsilon_{\mathrm{it}}
\end{aligned}
$$

Apart from using industry dummies $\left(D_{j}\right)$, the probit model also includes year dummies $\left(D_{k}\right)$ to control for a potential time effect, which might be driven by general policy or macroeconomic changes. The probit model refers to maximum likelihood estimation with heteroskedasticity-consistent variance estimation. Table 4 shows the results.

(Insert Table 4)

The first specification of the probit model (Model A) focuses on Hypotheses 2 and 6, whereas the extended Model B also incorporates internal and external governance mechanisms to test Hypothesis 4. The number of observations differs between both specifications because of missing values concerning governance variables. Due to a different sample size, it is not possible to compare specification A and B directly. To assess the robustness of the model specifications, we restrict the sample to 815 . Re-estimating the model specification A based on the restricted sample (model C) shows that the coefficients do not differ significantly from the model that includes corporate governance measures (model B).

Testing the importance of the Resource-based View for the decision to internationalize through M\&A (Hypothesis 2) implies the null-hypothesis that all firm-specific proxies linked to resources and capabilities are equal to zero $\left(\mathrm{H}_{0}: \delta_{1}=\ldots=\delta_{5}=0\right)$, which can be tested using an F-test. Besides testing the joint hypothesis, we can reveal individual variables that affect internationalization. Hypothesis 4 is tested in a similar manner. Next to the three probit specifications, Table 4 also shows the results of the F-tests for hypothesis 2,4 and 6 . The variable $H \_s h a r e$ is excluded in Model B as there are no cases of cross-border M\&A where an acquirer also issued $\mathrm{H}$-shares. The results support all three hypotheses - at least with reference to the joint hypothesis tests. Firm-specific variables linked to the Resource-based 
View (Hypothesis 2), corporate governance mechanisms (Hypothesis 4), as well as industryspecific effects (Hypothesis 6) all affect the binary choice between domestic and cross-border M\&A. Exploring partial effects of selected variables provides a more complex picture of underlying drivers of internationalization.

Acquirers that are more likely to enter foreign markets conduct fewer acquisitions (active) prior to market entry but exhibit higher goodwill relative to total assets (good). A high goodwill relative to total assets indicates past acquisitions, where the purchase price exceeded the target's net value of assets substantially due to intangible assets or synergies (i.e. brand, technology). Therefore, cross-border M\&A is more likely if Chinese acquirers develop experience from a few but substantial transactions with relatively high intangible assets. These partial effects disappear in specification B and C; however, a negative impact of SOEs emerges. The discrepancy in the model can be explained by the fact that private companies exhibit significantly higher goodwill (4.0\%) compared to SOEs $(2.9 \%)$ and private firms acquirer fewer targets (3.0 compared to 3.4). Accordingly, the significant impact of goodwill and activity in model $\mathrm{A}$ is replaced by the dominant underlying factor, namely state ownership in model B and C.

In line with Cui and Jiang (2009), Model B confirms that state-owned acquiring firms (gov) are less likely to conduct cross-border M\&A. Cui and Jiang (2009) contend that this finding might be due to political opposition in the respective host country. In addition, one needs to consider that most M\&A transactions are driven by the desire to restructure SOEs and not to acquire foreign assets. Based on the governance indicators, we cannot argue that better governance leads to more internationalization of Chinese firms, as the findings are mixed. Acquirers not controlled by the state (gov) and with a separation of the CEO position and the chairman of the board of directors (duality) were more likely to execute cross-border deals. These measures would indicate better internal governance. Nevertheless, acquirers that 
internationalized also had higher ownership concentration $(H I)$, which is an indicator for more dominant principal shareholders. In developed markets, high ownership concentration indicates weaker governance - but the same is not necessarily true in a less developed governance environment. In particular, in China the importance of the state declines - but another class of companies with high ownership concentration emerges: business groups. If we assume that business groups are associated with better internal governance than the state, a high ownership concentration does not necessarily imply weaker governance.

\subsection{Determinants of $M \& A$ success}

To test Hypotheses 1, 3, 5 and 7, we need to explain the success of M\&A, which includes domestic and cross-border transactions, using firm-specific proxies, industry-specific effects, and governance mechanisms. The specification of the model is similar to Equation 1, except that the dependent variable is the equally weighted cumulated abnormal return around the merger announcement $\left(C A R_{-} 1\right)$, and that explanatory variables incorporate deal-specific characteristics. Further, in order to test Hypothesis 1, the model includes a dummy variable for Chinese target firms $(\mathrm{ch})$. We estimate the following full specification with ordinary least squares and a heteroskedasticity-consistent variance estimator.

$$
\begin{aligned}
& C A R \_1_{i t}=\alpha+\sum_{j=1}^{7} \beta_{j} D_{j}+\sum_{k=1}^{62} \gamma_{k} D_{k}+\delta_{1} \text { leverage }{ }_{i t}+\delta_{2} \text { size }_{i t}+\delta_{3} R O E_{i t}+\delta_{4} g_{0 o d} \text { (2 } \\
& +\delta_{5} \text { active }_{i t}+\theta \text { tobin }_{q_{i t}}+\vartheta_{1} \text { gov }_{i t}+\vartheta_{2} \text { own }_{\text {share }}+\vartheta_{3} H I_{i t} \\
& +\vartheta_{4} \text { independent }_{i t}+\vartheta_{5} \text { board }_{i t}+\vartheta_{6} \text { duality }_{i t}+\vartheta_{7} \text { disclosure }_{i t} \\
& +\vartheta_{8} B_{-} \text {share }_{i t}+\vartheta_{9} H_{-} s h a r e_{i t}+\vartheta_{10} \text { legal }_{i t}+\mu_{1} \text { cash }_{i t}+\mu_{2} \text { ch }_{i t}+\mu_{3} m i \\
& +\mu_{4} a c q_{i t}+\mu_{5} \text { hor }_{i t}+\mu_{6} \text { rel_size } e_{i t}+\mu_{7} \text { tend }_{i t}+\mu_{8} \text { privat }_{i t}+\mu_{9} \text { divest }_{i} \\
& +\varepsilon_{i t}
\end{aligned}
$$

Table 5 shows the results of different model specifications of Equation 2 and reports the joint hypothesis F-tests, which support Hypotheses 3, 5 and 7. Firm-specific variables linked to the Resource-based View (Hypothesis 3), corporate governance mechanisms (Hypothesis 5), as well as industry-specific effects (Hypothesis 7) all possess explanatory 
power. Due to a high number of missing values after considering governance proxies, the sample size declines. To ensure comparability and to assess the relevance of corporate governance, we specify a model with and without governance variables based on the same sample. Consequently, the model specifications D and E as well as F and G can be compared directly. Given the same number of observations, the estimated coefficients do not change substantially. Adding governance measures improves the model fit indicated by a higher adjusted R-squared.

\section{(Insert Table 5)}

Model D focuses on the Resource-based View motivated firm-specific variables and the control variable Tobin's Q. Financial leverage and Tobin's Q have a negative and significant effect on cumulated abnormal returns (CAR_1); hence, acquirers with a high financial leverage and high valuation level have lower cumulated abnormal returns when they announced M\&A. Prior empirical literature shows that high valuation levels can trigger a contrarian effect to adjust the share price of overvalued acquirers (Dong et al., 2006). For acquirers with high financial leverage, acquisitions might further increase their financial risk. This has to be seen in light of the high percentage of cash transactions in China. With little equity finance, Chinese acquirers need to finance their M\&As either with internal sources (operating cash flow, retained earnings) or with external non-equity sources. Both worsen their financial leverage even more and increase their risk for current shareholders as well as debt holders. Chinese acquirers with high financial leverage may therefore have more difficulties to access additional capital - a vital resource for harvesting synergies from new business combinations.

Model E incorporates the deal specific variables as defined in Section 4. Financial leverage and Tobin's Q remain to be significant and negative drivers of M\&A success. The coefficient for the dummy for domestic mergers $(c h)$ is not statistically different from zero, 
which supports Hypothesis 1 . Chinese acquirers do not benefit from cross-border mergers, but they are also not worse off when compared with domestic M\&As. This is in line with previous findings for cross-border mergers by emerging market multinationals (Aybar and Ficici, 2009). Although Chinese mergers may, on average, be value enhancing (as shown in Table 1), cross-border mergers do not create more value than domestic deals. Cash mergers and privatisations trigger a higher market response, but both partial impacts are only significant on the $90 \%$ level of confidence. Relative size (rel_size) has a significant positive effect on M\&A success, which is counterintuitive based on empirical evidence for developed markets. However, acquisitions in China are very small, as even the largest acquisition only reaches $1.2 \%$ of the acquirer's assets.

Model $\mathrm{F}$ includes governance indicators for acquirers, which reduces the number of observations. Due to the different sample size it is not possible to directly compare the results of model D-E with Model F. Nevertheless, Hypothesis 1 is also supported in Model F as the effect of domestic mergers $(c h)$ remains statistically insignificant. Further, as expected in Hypothesis 5, the duality of the CEO position and chairman of the board of directors, good transparency in terms of disclosing the compensation of senior executives, and firms that issue H-shares are associated with higher cumulated returns. This can be interpreted as superior ownership in the form of better monitoring and alignment of shareholders' and executives' interests. Thus, in accordance with Hypothesis 5, we can conclude that Chinese acquirers with better governance benefit more from M\&As.

\section{Conclusion}

This paper analyses whether firm-, governance-, and industry-specific effects influence the decision to internationalize and whether these drivers impact on the success of M\&A conducted by Chinese acquirers. By using domestic and cross-border M\&A data from 4374 
Chinese deals announced from 2001 to 2008, the paper contributes the following key insights: Chinese cross-border mergers create shareholder value, but not more than domestic M\&As. We find significantly positive abnormal stock returns for Chinese mergers, both for equally weighted and value-weighted measures of success. However, in line with recent evidence on the internationalization of firms from emerging markets (Aybar and Ficici, 2009), shareholders of Chinese acquirers do not benefit more from cross-border mergers when compared with domestic M\&A. This implies that there are still sufficient expansion and consolidation possibilities within China that are at least as profitable as cross-border opportunities. Another result pointing into this direction is the relatively low share of crossborder M\&A in China compared with more mature markets.

Corporate governance plays an important role in Chinese M\&As. Joint hypothesis tests show that M\&A success and cross-border expansion are associated with internal and external governance mechanisms. In particular, government involvement decreases the likelihood for international mergers, probably because of political opposition in the host country, as contended by Cui and Jiang (2009). Moreover, the government has focused more on reorganising SOEs through domestic M\&A, which might also explain the low tendency of internationalization of Chinese SOEs. A favourable board structure in terms of separating the position of CEO and chairman of the board affects the likelihood of cross-border mergers and M\&A success. The latter is also positively related with proxies for corporate disclosure and dual listings at the Hong Kong Stock Exchange, which requires tighter regulations. Overall, the results support the notion that corporate governance and state ownership are crucial in Chinese M\&A decision making and success.

We can confirm that (i) firm-specific determinants that are related to the Resourcebased View as well as (ii) industry-specific fixed effects do not only matter in mature economies (Martynova and Renneboog, 2008), but also for Chinese acquirers. Joint 
hypothesis tests clearly show the explanatory power of these two dimensions, despite the idiosyncrasies of the Chinese governance and state ownership system.

Based on these findings, we can formulate the following recommendations for managers and policy makers: (1) improving internal and external governance mechanisms is vital to promote internationalization and to enhance the value creation potential from M\&A; (2) Chinese firms need to focus on maintaining a moderate level of financial leverage to ensure easy access to resources, which in turn supports value creation from M\&A. The latter recommendation might change if capital markets develop further (i.e. market for corporate bonds), payment in stock becomes more common, or state imposed restrictions on borrowing are abolished.

\section{References}

Agarwal, S., Ramaswami, S.N., 1992. Choice of foreign market entry mode: Impact of ownership, location and internalization factors. Journal of International Business Studies 23, 1-27.

Amit, R., Schoemaker, P.J.H., 1993. Strategic assets and organizational rent. Strategic Management Journal 14, 33-46.

Aybar, B., Ficici, A., 2009. Cross-border acquisitions and firm value: An analysis of emerging-market multinationals. Journal of International Business Studies 40, 1317 1338

Bai, C.-E., Liu Q., Lu, J., Song, F.M., Zhang, J., 2004. Corporate governance and market valuation in China. Journal of Comparative Economics 32, 599-616. 
Barney, J., Wright, M., Ketchen, D., 2001. The Resource-based View of the firm: Ten years after 1991. Journal of Management 27, 625-641.

Chen, X., Yuan, H., 1998. Financial and accounting investigation of the asset reconstruction of listed firms. China Accounting Research 10, 13-22.

Chen, X., Zhang, T., 1999. Market reaction of asset reconstruction: Empirical investigation of asset reconstruction of the Shanghai stock market in 1997. Economic Research 9, 47-

55.

Child, J., Rodrigues, S.B., 2005. The internationalization of Chinese firms: A case for theoretical extension? Management and Organization Review 1:3, 392.

Cui, L., Jiang, F., 2009. FDI entry mode choice of Chinese firms: A strategic behaviour perspective. Journal of World Business 44, 434-444.

Dong, M., Hirshleifer, D., Richardson, S., Teoh, S.H., 2006. Does investor misvaluation drive the takeover market? Journal of Finance 61, 725-762.

Doukas, J.A., Kan, O.B., 2006. Does global diversification destroy firm value? Journal of International Business Studies 37, 352-371.

Fan, G., Wang, X.L., 2004. Marketization index for China's provinces. Economy and Science Press.

Feng, G., Wu, L., 2001. Empirical investigation of Chinese listed companies M\&A performance. Economic Research 1, 54-61.

Fetscherin, M., Voss, H., Gugler, P., 2010. 30 years of foreign direct investment to China: An interdisciplinary literature review. International Business Review 19, 235-246.

Fuller, K., Netter, J., Stegemoller, M., 2002. What do returns to acquiring firms tell us? Evidence from firms that make many acquisitions, Journal of Finance 57, 1763-1793.

Gande, A., Schenzler, C., Senbet, L., 2009. Valuation effects of global diversification. Journal of International Business Studies 40, 1515-1532 
Gao, L., Kling, G., 2008. Equity transfers and market reactions: Evidence from Chinese stock market. Journal of Emerging Market Finance 7, 293-308.

Gao, L., Kling, G., 2008a. Corporate governance and tunneling in China. Pacific- Basin Finance Journal 16, 591-605.

Gao, W., Ng, L., Wang, Q., 2008. Does geographic dispersion affect firm valuation? Journal of Corporate Finance 14, 674-687.

Gozzi, J., Levine, R., Schmukler, S.L., 2008. Internationalization and the evolution of corporate valuation. Journal of Financial Economics 88, 607-632.

Graham, E. M., Pettis, M., 2005. Who's afraid of CNOOC? Far Eastern Economic Review, $168,24-29$.

Hair J, Anderson R, Tatham R, Black W., 1992. Multivariate Data Analysis. McMillan: New York,NY.

Hartzell, J. C., Ofek, E., Yermack, D., 2004. What's in it for me? CEOs whose firms are acquired. The Review of Financial Studies 17, 37-61.

Jensen, M.C., 1993. The modern industrial revolution, exit, and the failure of internal control systems. Journal of Finance 48, 831-881.

Liu, X., Buck, T., Shu, C., 2005. Chinese economic development, the next stage: outward FDI? International Business Review 14, 97-115.

Liu, G. S., Sun, P., 2005. The class of shareholdings and its impacts on corporate performance: A case of state shareholding composition in Chinese public corporations. Corporate Governance: An International Review 13, 46-59.

Luo, Y., Xue, Q., Han, B., 2010. How emerging market governments promote outward FDI: Experience from China. Journal of World Business 45, 68-79.

MacKinlay A.C., 1997. Event studies in economics and finance. Journal of Economic Literature 35, 13-39. 
Martynova, M., Renneboog, L., 2008. A century of corporate takeovers: What have we learned and where do we stand? Journal of Banking and Finance 32, 2148-2177.

Moeller, S.B., Schlingemann, F.P., Stulz, R.M., 2004. Firm size and the gains from acquisitions. Journal of Financial Economics 73, 201-228.

Moeller, S.B., Schlingemann, F.P., Stulz, R.M., 2005. Wealth destruction on a massive scale? A study of acquiring-firm returns in the recent merger wave. Journal of Finance 60, 757-782.

Quiang, Q., 2003. Corporate governance and state-owned shares in China listed companies. Journal of Asian Economics 14, 771-783.

Rossi, S., Volpin, P.F., 2004. Cross-country determinants of mergers and acquisitions, Journal of Financial Economics 74, 277-304.

Studenmund A.H. (1992). Using econometrics: A practical guide. Harper Collins: New York.

Sudarsanam, S. (2003). Creating value from mergers and acquisitions. Prentice Hall, Essex, UK.

Tichy, G., 2001. What do we know about success and failure of mergers? Journal of Industry, Competition and Trade 1, 347-394.

UNCTAD, 2000. World investment report 2000: Cross-border mergers and acquisitions and development. UNCTAD, New York.

Weitzel, U., Berns, S., 2006. Cross-border takeovers, corruption, and related aspects of governance. Journal of International Business Studies 37, 786-806.

Wernerfelt, B., 1984. A resource-based view of the firm, Strategic Management Journal 5, 171-180.

Yermack, D., 1996. Higher market valuation of companies with a small board of directors. Journal of Financial Economics 40, 185-211. 
Yip, G.S., 1992. Total global strategy: Managing for worldwide competitive advantage. Englewood Cliffs, N.J.: Prentice-Hall.

Zhang, Z., 2007. Legal deterrence: the foundation of corporate governance - evidence from China. Corporate Governance: An International Review 15, 747-767.

Zhang, X., 2003. The sustainability of China's economic growth from the viewpoint of listed Chinese companies' performance. Comparison of Economic and Social Systems 1, $41-48$

Zollo, M., Meier D., 2008. What is M\&A performance. The Academy of Management Perspectives 22, 55-77. 


\section{Table 1}

M\&A activity, deal structure and success

\begin{tabular}{llllllllll}
\hline \multicolumn{3}{l}{ Number and type of transaction } & & & \multicolumn{2}{c}{ Volume of M\&A } & \multicolumn{2}{l}{ Success of M\&A } \\
\hline year & $\begin{array}{l}\text { Cross- } \\
\text { border }\end{array}$ & Domestic & Total & $\begin{array}{l}\text { Cash } \\
\text { mergers }\end{array}$ & $\begin{array}{l}\text { State- } \\
\text { led } \\
\text { M\&A }\end{array}$ & $\begin{array}{l}\text { Deal } \\
\text { volume } \\
\text { (\$ mil) }\end{array}$ & $\begin{array}{l}\text { Volume } \\
\text { per deal } \\
\text { (\$ mil) }\end{array}$ & $\begin{array}{l}\text { CAR_1 } \\
\text { (equal } \\
\text { weight) }\end{array}$ & $\begin{array}{l}\text { CAR_1 } \\
\text { (value } \\
\text { weight) }\end{array}$ \\
\hline 2001 & 18 & 117 & 135 & $91.9 \%$ & $20.7 \%$ & 4826 & 35.8 & $3.11 \%$ & $-0.66 \%$ \\
2002 & 25 & 279 & 304 & $96.1 \%$ & $39.8 \%$ & 9386 & 30.9 & $0.80 \%$ & $0.06 \%$ \\
2003 & 19 & 538 & 557 & $96.9 \%$ & $51.0 \%$ & 9298 & 16.7 & $-0.70 \%$ & $0.00 \%$ \\
2004 & 21 & 672 & 693 & $98.1 \%$ & $41.7 \%$ & 15690 & 22.6 & $-0.58 \%$ & $0.00 \%$ \\
2005 & 30 & 481 & 511 & $95.3 \%$ & $38.9 \%$ & 10009 & 19.6 & $-0.22 \%$ & $0.01 \%$ \\
2006 & 34 & 536 & 570 & $96.0 \%$ & $38.9 \%$ & 28195 & 49.5 & $2.17 \%$ & $0.02 \%$ \\
2007 & 40 & 728 & 768 & $97.1 \%$ & $29.2 \%$ & 57946 & 75.5 & $3.58 \%$ & $0.01 \%$ \\
2008 & 25 & 811 & 836 & $98.6 \%$ & $29.2 \%$ & 70292 & 84.1 & $-1.18 \%$ & $0.00 \%$ \\
\hline Total & 212 & 4162 & 4374 & $96.9 \%$ & $36.8 \%$ & 205643 & 47.0 & $0.54 \% * * *$ & $0.01 \% * * *$ \\
\hline Note: *** p<0.01 & & & & & & & &
\end{tabular}




\section{Table 2}

Change of internal and external governance mechanisms

\begin{tabular}{lllllllllll}
\hline year & gov & own_share & HI & independent & board & duality & disclosure & B_share & H_share & legal \\
\hline 2001 & 0.207 &. & 0.281 & 0.024 & 9.227 & 0.118 & 0.279 & 0.147 & 0.059 & 5.808 \\
2002 & 0.398 &. & 0.297 & 0.071 & 9.101 & 0.133 & 0.020 & 0.093 & 0.007 & 5.898 \\
2003 & 0.510 & 0.000 & 0.311 & 0.255 & 9.788 & 0.104 & 0.040 & 0.074 & 0.003 & 5.875 \\
2004 & 0.417 & 0.001 & 0.283 & 0.329 & 10.138 & 0.128 & 0.007 & 0.036 & 0.002 & 5.689 \\
2005 & 0.389 & 0.005 & 0.266 & 0.344 & 9.579 & 0.125 & 0.044 & 0.037 & 0.000 & 5.909 \\
2006 & 0.389 & 0.002 & 0.222 & 0.348 & 9.404 & 0.130 & 0.796 & 0.065 & 0.006 & 5.866 \\
2007 & 0.292 &. & 0.198 & 0.358 & 9.500 & 0.101 & 0.947 & 0.035 & 0.002 & 5.922 \\
2008 & 0.292 &. & 0.205 & 0.332 & 9.305 & 0.157 & 0.974 & 0.045 & 0.002 & 5.728 \\
\hline Total & 0.368 & 0.002 & 0.243 & 0.310 & 9.554 & 0.127 & 0.530 & 0.051 & 0.004 & 5.822 \\
\hline
\end{tabular}




\section{Table 3}

Pairwise correlation and variance inflation factor (VIF) test for multicollinearity

\begin{tabular}{|c|c|c|c|c|c|c|c|c|c|c|c|c|c|c|c|c|c|c|c|c|c|c|c|c|c|c|c|}
\hline & VIF & 1 & 2 & 3 & 4 & 5 & 6 & 7 & 8 & 9 & 10 & 11 & 12 & 13 & 14 & 15 & 16 & 17 & 18 & 19 & 20 & 21 & 22 & 23 & 24 & 25 & 26 \\
\hline \begin{tabular}{|l|} 
CAR_1 \\
\end{tabular} & & 1.00 & & & & & & & & & & & & & & & & & & & & & & & & & \\
\hline leverage & 2.57 & $\begin{array}{ll}-0.04 \\
\end{array}$ & 1.00 & & & & & & & & & & & & & & & & & & & & & & & & \\
\hline size & 1.63 & 0.00 & 0.03 & 1.00 & & & & & & & & & & & & & & & & & & & & & & & \\
\hline ROE & 2.58 & -0.01 & -0.11 & 0.02 & 1.00 & & & & & & & & & & & & & & & & & & & & & & \\
\hline tobin_q & 1.29 & -0.01 & 0.00 & -0.20 & 0.00 & 1.00 & & & & & & & & & & & & & & & & & & & & & \\
\hline good & 1.11 & -0.01 & 0.05 & -0.15 & 0.03 & -0.01 & 1.00 & & & & & & & & & & & & & & & & & & & & \\
\hline active & 1.08 & -0.01 & 0.00 & 0.22 & -0.05 & -0.03 & 0.00 & 1.00 & & & & & & & & & & & & & & & & & & & \\
\hline cash & 1.04 & 0.00 & 0.04 & 0.05 & 0.05 & 0.00 & -0.03 & 0.06 & 1.00 & & & & & & & & & & & & & & & & & & \\
\hline $\mathrm{ch}$ & 1.07 & -0.01 & 0.00 & 0.01 & -0.01 & 0.00 & -0.04 & 0.01 & 0.02 & 1.00 & & & & & & & & & & & & & & & & & \\
\hline $\min$ & 1.21 & -0.01 & -0.01 & -0.02 & 0.01 & -0.01 & -0.02 & 0.01 & 0.05 & 0.00 & 1.00 & & & & & & & & & & & & & & & & \\
\hline acq & 1.30 & 0.00 & -0.01 & 0.07 & 0.01 & $\begin{array}{l}-0.02 \\
\end{array}$ & 0.00 & 0.06 & 0.03 & 0.02 & -0.22 & 1.00 & & & & & & & & & & & & & & & \\
\hline hor & $\begin{array}{ll}1.07 \\
\end{array}$ & 0.00 & -0.01 & 0.13 & 0.00 & 0.03 & -0.05 & 0.08 & 0.03 & -0.03 & -0.12 & 0.14 & 1.00 & & & & & & & & & & & & & & \\
\hline rel_size & 1.31 & 0.06 & 0.01 & -0.42 & -0.03 & 0.16 & 0.09 & -0.17 & -0.14 & -0.08 & 0.07 & $\begin{array}{ll}-0.18 \\
\end{array}$ & $\begin{array}{ll}-0.07 \\
\end{array}$ & 1.00 & & & & & & & & & & & & & \\
\hline tend & 1.04 & 0.03 & 0.01 & -0.02 & 0.00 & 0.01 & 0.05 & -0.02 & 0.01 & -0.03 & -0.04 & 0.19 & -0.02 & 0.07 & 1.00 & & & & & & & & & & & & \\
\hline privat & 1.24 & 0.04 & 0.05 & 0.05 & -0.01 & -0.01 & 0.03 & -0.01 & 0.01 & 0.03 & -0.09 & -0.10 & 0.05 & 0.06 & -0.04 & 1.00 & & & & & & & & & & & \\
\hline divest & \begin{tabular}{ll|}
1.37 \\
\end{tabular} & 0.03 & 0.01 & -0.08 & -0.03 & 0.04 & 0.03 & -0.06 & -0.12 & -0.01 & -0.31 & -0.22 & 0.10 & 0.16 & -0.09 & 0.27 & 1.00 & & & & & & & & & & \\
\hline gov & 1.42 & 0.03 & 0.02 & 0.14 & 0.01 & $\begin{array}{ll}-0.03 \\
\end{array}$ & -0.04 & 0.04 & 0.02 & 0.06 & 0.04 & -0.05 & 0.07 & -0.06 & -0.08 & 0.33 & 0.03 & 1.00 & & & & & & & & & \\
\hline own_share & 1.06 & 0.01 & -0.01 & -0.10 & 0.00 & -0.05 & -0.04 & -0.03 & 0.03 & 0.02 & -0.02 & 0.03 & -0.02 & 0.00 & -0.01 & -0.03 & -0.02 & -0.10 & 1.00 & & & & & & & & \\
\hline \begin{tabular}{|l|}
$\mathrm{HI}$ \\
\end{tabular} & 1.35 & -0.01 & -0.01 & 0.16 & 0.00 & -0.06 & -0.08 & 0.08 & 0.00 & 0.01 & 0.01 & -0.02 & 0.09 & \begin{tabular}{|l|}
-0.13 \\
\end{tabular} & -0.03 & -0.07 & $\begin{array}{l}-0.03 \\
\end{array}$ & 0.34 & -0.08 & 1.00 & & & & & & & \\
\hline independent & 1.21 & 0.05 & -0.01 & 0.04 & 0.01 & 0.03 & 0.00 & 0.01 & 0.01 & 0.05 & -0.07 & 0.07 & 0.03 & 0.00 & -0.03 & 0.05 & 0.01 & -0.03 & 0.09 & -0.08 & 1.00 & & & & & & \\
\hline board & 1.20 & -0.02 & 0.00 & 0.26 & 0.02 & -0.02 & -0.05 & 0.10 & 0.02 & 0.00 & -0.01 & 0.01 & 0.10 & -0.15 & -0.03 & 0.06 & -0.02 & 0.08 & -0.02 & 0.00 & -0.11 & 1.00 & & & & & \\
\hline \begin{tabular}{|l} 
duality \\
\end{tabular} & 1.05 & 0.00 & 0.00 & -0.04 & -0.07 & 0.00 & -0.03 & 0.10 & 0.00 & -0.01 & 0.01 & 0.03 & 0.01 & 0.02 & -0.02 & -0.06 & -0.03 & -0.04 & 0.04 & 0.00 & 0.06 & -0.08 & 1.00 & & & & \\
\hline disclosure & 1.08 & 0.09 & 0.02 & 0.14 & -0.04 & 0.05 & 0.04 & 0.01 & 0.01 & 0.01 & -0.06 & 0.03 & 0.01 & 0.08 & 0.00 & 0.10 & 0.01 & -0.10 & 0.12 & -0.21 & 0.27 & -0.07 & 0.00 & 1.00 & & & \\
\hline B_share & 1.13 & \begin{tabular}{|c|}
-0.01 \\
\end{tabular} & -0.03 & 0.13 & 0.01 & $\begin{array}{l}-0.01 \\
\end{array}$ & 0.00 & $\begin{array}{l}-0.07 \\
\end{array}$ & -0.02 & 0.00 & 0.05 & 0.01 & 0.05 & \begin{tabular}{ll|}
-0.01 \\
\end{tabular} & 0.01 & -0.03 & $\begin{array}{ll}-0.02 \\
\end{array}$ & $\begin{array}{l}-0.02 \\
\end{array}$ & $\begin{array}{ll}-0.03 \\
\end{array}$ & -0.05 & -0.06 & 0.03 & $\begin{array}{l}-0.04 \\
\end{array}$ & $\begin{array}{l}-0.03 \\
\end{array}$ & 1.00 & & \\
\hline H_share & 1.03 & 0.02 & -0.01 & 0.08 & 0.01 & 0.00 & 0.04 & 0.02 & -0.05 & 0.01 & -0.02 & 0.01 & 0.06 & $\begin{array}{ll}-0.04 \\
\end{array}$ & 0.00 & 0.00 & 0.03 & 0.08 & -0.01 & 0.02 & 0.01 & 0.00 & -0.02 & \begin{tabular}{|l|}
-0.03 \\
\end{tabular} & -0.01 & 1.00 & \\
\hline legal & 1.14 & 0.02 & -0.02 & 0.16 & 0.05 & -0.02 & -0.17 & 0.03 & 0.05 & -0.02 & 0.03 & 0.04 & 0.04 & -0.09 & 0.01 & -0.04 & \begin{tabular}{|l|}
-0.07 \\
\end{tabular} & 0.01 & 0.03 & 0.05 & 0.04 & 0.01 & 0.06 & \begin{tabular}{|l|}
-0.01 \\
\end{tabular} & 0.15 & 0.02 & 1.00 \\
\hline
\end{tabular}

Note: all correlation coefficients larger than $|0.05|$ are statistically significant at the $1 \%$ level. 
Table 4

Results of probit estimations (dependent: cross)

\begin{tabular}{|c|c|c|c|}
\hline Variable & A & B & $\mathrm{C}$ \\
\hline leverage & 0.00 & 0.01 & 0.01 \\
\hline size & 0.01 & -0.16 & -0.01 \\
\hline ROE & 0.01 & $0.03 *$ & 0.02 \\
\hline tobin_q & -0.06 & -0.32 & -0.30 \\
\hline good & $2.04 * *$ & -2.05 & -3.02 \\
\hline active & $-0.04 *$ & -0.04 & -0.04 \\
\hline buy_gov & & $-1.01 * * *$ & \\
\hline own_share & & -25.66 & \\
\hline $\mathrm{HI}$ & & $1.49 * *$ & \\
\hline independent & & 1.25 & \\
\hline board & & 0.07 & \\
\hline duality & & $0.49 *$ & \\
\hline disclosure & & -0.46 & \\
\hline B_share & & 0.43 & \\
\hline legal & & 0.09 & \\
\hline Constant & $-6.50 * * *$ & -2.86 & -4.50 \\
\hline Observations & 2028 & 813 & 813 \\
\hline Pseudo $\mathrm{R}^{2}$ & 0.12 & 0.21 & 0.14 \\
\hline \multicolumn{4}{|c|}{ F-tests for industry effects and year dummies } \\
\hline & F-test & P-value & \\
\hline Hypothesis 2 & $11.20 * *$ & 0.048 & \\
\hline Hypothesis 4 & $18.63 * *$ & 0.017 & \\
\hline Hypothesis 6 & $261.87 * * *$ & 0.000 & \\
\hline Year effects & $31.33 * * *$ & 0.000 & \\
\hline
\end{tabular}

Note: $* \mathrm{p}<0.1, * * \mathrm{p}<0.05, * * * \mathrm{p}<0.01$; heteroskedasticity-consistent estimator of variance; year and industry (2-digit SIC) fixed effects included. 
Table 5

Results of OLS regressions (dependent: $C A R \_1$ )

\begin{tabular}{|c|c|c|c|c|}
\hline Variable & $\mathrm{D}$ & $\mathrm{E}$ & $\mathrm{F}$ & $\mathrm{G}$ \\
\hline leverage & $-0.02 * * *$ & $-0.02 * * *$ & -0.01 & -0.01 \\
\hline size & 0.01 & 0.12 & 0.33 & 0.31 \\
\hline ROE & -0.02 & -0.03 & $0.11^{*}$ & $0.11 *$ \\
\hline tobin_q & $-0.01 * * *$ & $-0.02 * * *$ & 0.32 & 0.07 \\
\hline good & -1.15 & -1.57 & 1.2 & 1.79 \\
\hline active & -0.04 & -0.02 & -0.06 & -0.04 \\
\hline cash & & $1.53 *$ & 1.77 & $1.73 *$ \\
\hline ch & & 0.32 & -1.88 & -1.95 \\
\hline $\min$ & & -0.03 & $1.33 *$ & 1.26 \\
\hline acq & & 0.20 & 0.82 & 0.75 \\
\hline hor & & 0.35 & 0.31 & 0.24 \\
\hline rel_size & & $0.22 * *$ & $0.32 * *$ & $0.37 * * *$ \\
\hline tend & & 1.19 & 1.09 & 1.76 \\
\hline privat & & $1.06^{*}$ & 0.89 & 1.08 \\
\hline divest & & 0.36 & 0.74 & 0.65 \\
\hline gov & & & 0.24 & \\
\hline own_share & & & 6.63 & \\
\hline $\mathrm{HI}$ & & & 1.49 & \\
\hline independent & & & 1.05 & \\
\hline board & & & -0.05 & \\
\hline duality & & & $1.49 * *$ & \\
\hline disclosure & & & $1.79 * * *$ & \\
\hline B_share & & & -0.18 & \\
\hline H_share & & & $3.25^{* *}$ & \\
\hline legal & & & -0.14 & \\
\hline Constant & -1.89 & -2.04 & -5.14 & -3.43 \\
\hline Observations & 2237 & 2237 & 1081 & 1081 \\
\hline Adjusted $\mathrm{R}^{2}$ & 0.05 & 0.06 & 0.13 & 0.11 \\
\hline \multicolumn{5}{|c|}{ F-tests for industry effects and year dummies } \\
\hline & F-test & P-value & & \\
\hline Hypothesis 3 & $4.85 * * *$ & 0.00 & & \\
\hline Hypothesis 5 & $2.84 * * *$ & 0.00 & & \\
\hline Hypothesis 7 & $6922.67 * * *$ & 0.00 & & \\
\hline Year effects & $3.82 * * *$ & 0.01 & & \\
\hline
\end{tabular}

Note: $* \mathrm{p}<0.1, * * \mathrm{p}<0.05, * * * \mathrm{p}<0.01$; heteroskedasticity-consistent estimator of variance; year and industry (2-digit SIC) fixed effects included. 


\section{Appendix}

\begin{tabular}{|c|c|c|}
\hline Variables & Type & Description \\
\hline \multicolumn{3}{|c|}{ Panel A: Deal-related variables } \\
\hline CAR_1 & $\begin{array}{l}\text { dependent: } \\
\mathrm{H} 3,5,7\end{array}$ & $\begin{array}{l}\text { cumulated abnormal return of the acquirer for the event } \\
\text { window one day before the merger announcement until one day } \\
\text { after (winsorized between 5\% and 95\%) }\end{array}$ \\
\hline cash & control & $\begin{array}{l}\text { payment method: dummy indicating a cash component }>90 \% \text { of } \\
\text { the total deal value }\end{array}$ \\
\hline $\mathrm{ch}$ & Main: H1 & $\begin{array}{l}\text { dummy indicating domestic M\&As (target is a Chinese } \\
\text { company) }\end{array}$ \\
\hline cross & $\begin{array}{l}\text { dependent: } \\
\mathrm{H} 2,4,6\end{array}$ & $\begin{array}{l}\text { dummy indicating crossborder M\&As (target is not a Chinese } \\
\text { company) }\end{array}$ \\
\hline $\begin{array}{l}\text { min, acq, } \\
\text { merger }\end{array}$ & control & $\begin{array}{l}\text { type of acquisition: } \\
\text { min refers to the acquisition of a minority interest } \\
\text { acq refers to acquiring equity after reaching } 50 \% \text { of ownership } \\
\text { (no change of control) } \\
\text { merger refers to a change of control (acquirer owns less than } \\
50 \% \text { before transaction and more than } 50 \% \text { after transaction) - } \\
\text { reference category in estimations }\end{array}$ \\
\hline hor & control & $\begin{array}{l}\text { dummy indicating horizontal M\&As based on identical first } \\
\text { two digits of SIC codes }\end{array}$ \\
\hline rel_size & control & Log of the ratio deal value divided by total assets of acquirer \\
\hline tend & control & dummy indicating a tender offer \\
\hline privat & control & dummy indicating that target was privatized \\
\hline divest & control & dummy indicating that target was a divestiture \\
\hline \multicolumn{3}{|c|}{ Panel B: Firm-specific variables } \\
\hline leverage & main: $\mathrm{H} 2,3$ & total debt divided by total equity \\
\hline size & main: $\mathrm{H} 2,3$ & natural logarithm of acquirer's total assets \\
\hline ROE & main: $\mathrm{H} 2,3$ & return on equity \\
\hline tobin_q & control & $\begin{array}{l}\text { market value of all firm assets (equity and debt) divided by the } \\
\text { book value of assets }\end{array}$ \\
\hline good & main: $\mathrm{H} 2,3$ & $\begin{array}{l}\text { value of goodwill of acquirer divided by the book value of total } \\
\text { assets }\end{array}$ \\
\hline active & main: $\mathrm{H} 2,3$ & number of previous mergers \\
\hline \multicolumn{3}{|c|}{ Panel C: Internal and external governance variables } \\
\hline own_share & main: $\mathrm{H} 4,5$ & $\begin{array}{l}\text { percentage of stocks held by senior managers (board members } \\
\text { and top management) }\end{array}$ \\
\hline HI & main: $\mathrm{H} 4,5$ & $\begin{array}{l}\text { standardized Herfindahl index based on ownership of } 10 \text { largest } \\
\text { shareholders; } \\
1 \text { indicates the highest and } 0 \text { the lowest level of concentration }\end{array}$ \\
\hline independent & main: $\mathrm{H} 4,5$ & ratio of independent directors \\
\hline board & main: $\mathrm{H} 4,5$ & size of board of directors (number of directors) \\
\hline duality & main: $\mathrm{H} 4,5$ & $\begin{array}{l}\text { dummy indicating that CEO concurrently serves as board } \\
\text { director }\end{array}$ \\
\hline
\end{tabular}




\begin{tabular}{|l|l|l|} 
disclosure & main: H4,5 & dummy indicating the disclosure of top managers' salaries \\
\hline gov & main: H4,5 & dummy indicating a state-owned acquirer \\
\hline B_share & main: H4,5 & dummy indicating a company with B-shares \\
\hline H_share & main: H4,5 & dummy indicating a company with H-shares \\
\hline legal & main: H4,5 & $\begin{array}{l}\text { degree of regional legal system and intermediary organizations } \\
\text { development }\end{array}$ \\
\hline Panel D: Fixed effects \\
\hline $\begin{array}{l}\text { industry } \\
\text { effects }\end{array}$ & main: H6,7 & $\begin{array}{l}\text { 64-1 dummies for each unique pair of the first two digits of SIC } \\
\text { codes }\end{array}$ \\
\hline year effects & control & 8-1 dummies for each year \\
\hline
\end{tabular}

